Proceedings of the International Conference on Teaching, Education and Learning Conference, Vol. 1, 2021, pp. 99-114 Copyright (C) 2021 iConferences

ISSN 2820-2155

DOI: https://doi.org/10.32789/tel.2021.1008

The Behavior of Educational Organizations during the Covid-19 Period (Literature Review)

\author{
Gamal Muhammad Rizka
}

Educational Administration, University of Lampung, Indonesia, gamal.rizka@staff.itera.ac.id 


\title{
THE BEHAVIOR OF EDUCATIONAL ORGANIZATIONS DURING THE COVID-19 PERIOD (LITERATURE REVIEW)
}

\begin{abstract}
The purpose of this study is to determine the condition of the school organization during a pandemic Covid-19, from the scope of individuals, social groups, relations between organizations, relations between institutions, and related policies in special conditions such as during a pandemic Covid-19 this time. The subject of this study is a literature review, literature sources that discuss pandemics, conditions, individual attitudes in school organizations, social group relations, communities, institutions, and related policies in special conditions such as during the pandemic Covid-19 this time. The time of the pandemic has various implications sector, including sector education. As a complex system, the organization is expected to become an organization that can promote healthy behavior physically and mentally during a pandemic. The school organization is covered by individuals with knowledge, attitudes, and behaviors. The results of this study explain that for schools to remain focused on achieving educational goals with good quality, the integration of functions between school principals, teachers, and all school resources, groups of educators and education staff organizations, between organizations, institutions in society, and policies issued must go in harmony with future study.
\end{abstract}

Keywords: School organization, Covid-19, education

\section{Introduction}

The outbreak of the coronavirus disease, known as Covid-19, in December 2019 in Wuhan caused a tremendous amount of panic. Transmission is very easy and fast, and the absence of a covid-19 antivirus has made various countries improve vigilance against the entry of this virus into their countries. However, these efforts seem to fail. It is proven that this outbreak has spread to more than 200 countries in Indonesia and the world and was declared a pandemic (Jamaluddin, Ratnasih, Gunawan, \& Paujiah, 2020).

Covid-19 has infected billions of people around the world. The impact on the economy is more visible and has the potential to lead to a global recession. Millions of people wealthy people can become poor (Suryahadi et al., 2020). In the education sector, government policies in dealing with pandemics aim to eliminate face-to-face learning by enforcing online learning (Pujilestari, 2020).

The education sector has experienced a significant impact on the emergence of this pandemic. Not only schools must implement online learning, but also problems arise in school conditions, the economy of parents of students, and different geographical conditions. In addition to other problems that arise in the form of lack of technological literacy, limited budget, inadequate communication service providers, parents have not been maximal in assisting children; teacher working hours are not limited to communicating and coordinating with parents, fellow teachers, and school leaders 
(Purwanto et al., 2020). Schools become a place to control the spread of disease because schools in several areas are connected to health activities or sectors. School leaders and teachers can create a strategy to disseminate information about the protocol for tackling a pandemic, especially for school residents (World Bank Group Education, 2020).

Massive efforts are being made by schools and teachers at all levels to create online courses and deliver them through TV broadcasts and the internet in record time. The new virtual semester has just started in many parts of the country, and various courses are offered online well organized. These actions are helping to alleviate many parents' concerns about their children's educational attainment by ensuring that school learning is largely undisrupted. Although these measures and efforts are highly commendable and necessary, there are reasons to be concerned because prolonged school closure and home confinement during a disease outbreak might have negative effects (G Wang et al., 2020).

However, it is not only the closure of schools but scientists and policymakers must provide alternative activities that can be applied to various problems such as the emergence of unexpected costs or problems regarding human resources. Besides, the educational model after the pandemic is expected to be implemented following health protocols (Viner et al., 2020).

The dynamics of schooling during a pandemic are necessarily pictured so that the right program could be designed. The dynamics of schooling are that the school organization consists of various elements, both human and non-human elements. Humans have cultural capital and knowledge that shape their behavior and attitudes. Non-human elements become capital objects in carrying out tasks and achieving organizational goals. Besides, schools are multi-layered institutions and are related both internally and across sectors, in which there are people with cultural capital and knowledge. Therefore, school studies are very organizational important for manifest policies that could well be implemented.

\section{Methodology}

To obtain a comprehensive scientific knowledge framework, this article uses a literature review. The literature review was carried out by reviewing texts that discuss how the pandemic in Indonesia emerged; schools are organizations affected. Therefore, schools must defend themselves by adjusting the strengths they have with the existing challenges. 
The study in this manuscript is in the form of a manuscript that discusses the school in terms of individuals collected in a layered system starting from the national level, local government, district government, and education units. The manuscripts are in the form of research reports, theoretical frameworks, observational studies, experimental, and manuscripts policy.

The policy review manuscript begins with circular letter number 4 of 2020 about the implementation of education policies in emergency periods coronavirus disease (Covid-19), circular letter number 15 of 2020 concerning guidelines for organizing learning from home in the spread of emergency covid19. The regulation of the minister of health of the Republic of Indonesia number 9 of 2020 regarding the guidelines for large-scale social restrictions in the context of acceleration handling of coronavirus disease 2019 (Covid-19), and several decisions of governors regarding the learning process in each province. For the study, the global journal article manuscripts studied are school closure and management practices during coronavirus outbreaks including covid-19: a rapid systematic review, the impact of covid-19 outbreak on poverty: an estimation for Indonesia, mitigate the effects of home confinement on children during the covid-19 outbreak and reopening of school in Covid-19 Pandemic. Apart from that, a text on education management and leadership is also a source of study. Scientific texts studied with classify categories that indicate the school consists of agents, actors, individuals covered by the broader system, but schools are required to achieve the same goal of realizing human resources quality, even during a pandemic.

This study includes quantitative studies using diverse designs to model or empirically evaluate the effects of school closure and other school social distancing practices on infection rates and transmission during coronavirus outbreaks.

\section{Results}

The broadest scope of socio-ecology is the social sphere; the social sphere consists of various policies at both national and local levels related to economy, politics, social, health, education, which are related to events, in this case, the emergence of a pandemic. The social sphere in the form of educational policies during the pandemic, the policies designed are circular letter number 4 of 2020 concerning the implementation of educational policies in an emergency period of the spread of the virus (Ministry of Education and Culture, 2020). Related to the education scope is a circular directly compiled by the ministry of education, based on references to health and epidemic prevention. 


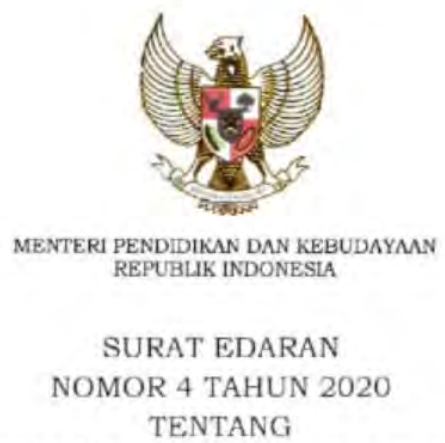

PELAKSANAAN KEBIJAKAN PENDIDIKAN DALAM MASA DARURAT PENYEBARAN CORONAVIRUS DISEASE (COVID-19)

Yth.

1. Gubernur;

2. Bupati/Walikota,

di seluruh Indonesia.

Berkenaan dengan penyebaran Coronavirus Disease (Covid-19) yang semakin meningkat maka kesehatan lahir dan batin siswa, guru, kepala sekolah dan seluruh warga sekolah menjadi pertimbangan utama dalam pelaksanaan kebijakan pendidikan.

Figure 1: Circular Letter Number 4 of 2020 cConcerning Implementation of Education Policy

This circular from the Minister of Education and Culture is addressed to governors and regents/mayors throughout Indonesia. This document was circulated primarily to consider students, teachers, and all school residents' physical and mental health amid the threat of Covid-19.

The first point conveyed by the Minister of Education and Culture in this letter is about the cancellation of the 2020 National Examination (UN). As a consequence, UN 2020 participation is not a requirement for graduation or higher-level promotion. Apart from the UN, the cancellation also includes the 2020 Skills Competency Test for Vocational High Schools. What determines graduation in 2020 is the School Examination regulated in the third point of this circular.

A significant issue discussed was regarding the Admission of New Students (PPDB) during the pandemic. The Minister of Education and Culture asked the Education Office and schools to regulate the PPDB mechanism with strict health protocols. It also states the provisions for the PPDB achievement path. 
Structurally, the Minister of Education and Culture SE No 4/2020 consists of two pages containing six important points. These points are related to the National Examination, the learning process from home, the School Examination, class promotion, Admission of New Students, and School Operational Assistance (BOS) funds, respectively.

These points are arranged to pay attention to the continuity of education in a conducive way in the midst of the Covid-19 pandemic.

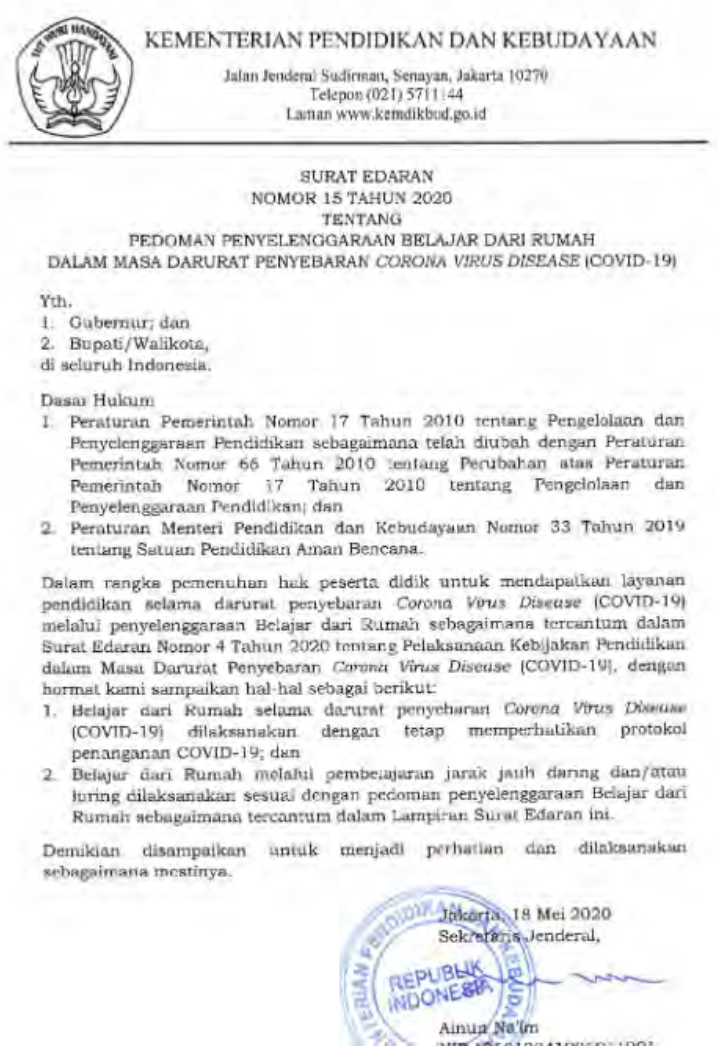

Figure 2: Guidelines for Organizing Learning from Home in an Emergency for the Spread of Covid-19 
The Ministry of Education and Culture (Kemendikbud) also issued Circular Letter Number 15 of 2020 concerning Guidelines for Organizing Learning from Home in an Emergency for the Spread of Covid-19. This Circular Letter Number 15 is to strengthen the Circular of the Minister of Education and Culture Number 4 of 2020 concerning the Implementation of Education in the Coronavirus Disease (Covid-19) Emergency Period.

In this circular, it is stated that the purpose of implementing Learning From Home (BDR) is to ensure the fulfillment of students' rights to get educational services during the Covid-19 emergency, protect education unit residents from the adverse effects of Covid-19, prevent the spread and transmission of Covid-19 in education unit and ensure the fulfillment of psychosocial support for educators, students, and parents.

In principle, the safety and inner health of students, educators, school principals, and all members of the education unit are the main considerations in implementing learning from home.

BDR activities are carried out to provide meaningful learning experiences for students without being burdened with demands to complete all curriculum achievements and are focused on life skills education, including regarding the Covid-19 pandemic. "Learning materials are inclusive in accordance with the age and level of education, cultural context, character, and type of specificity of students.

BDR activities and assignments may vary between regions, educational units, and students according to their respective interests and conditions, including considering gaps in access to BDR facilities. "The learning outcomes of students during BDR are given qualitative and useful feedback from the teacher without being required to give quantitative scores/scores, as well as emphasizing positive interaction and communication patterns between teachers and parents. In Regions Also Has Issued A Policy To Prevent The Spread Of The Covid-19 Virus.

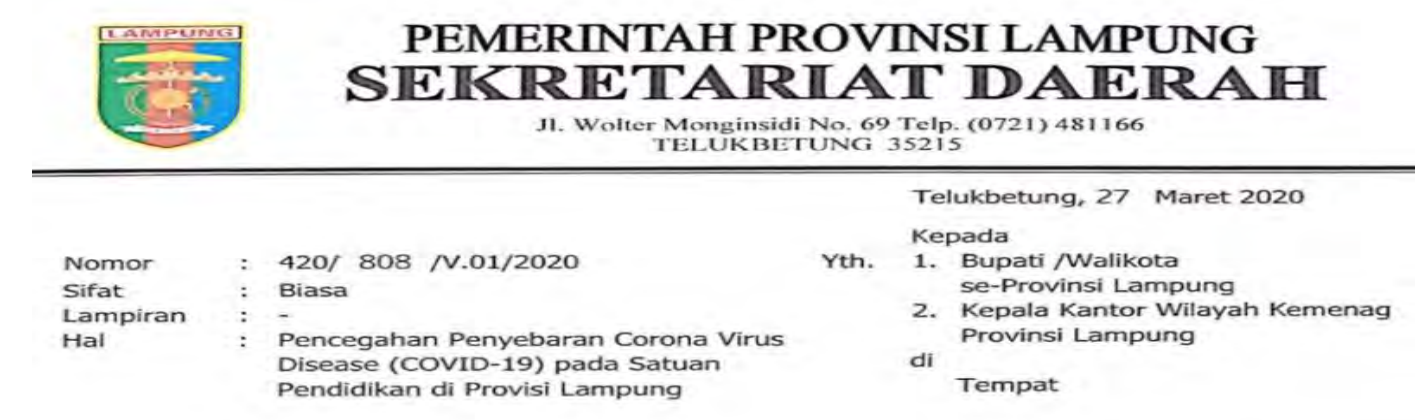

Figure 3. Prevention of the Spread of the Covid-19 Virus in Lampung Province 


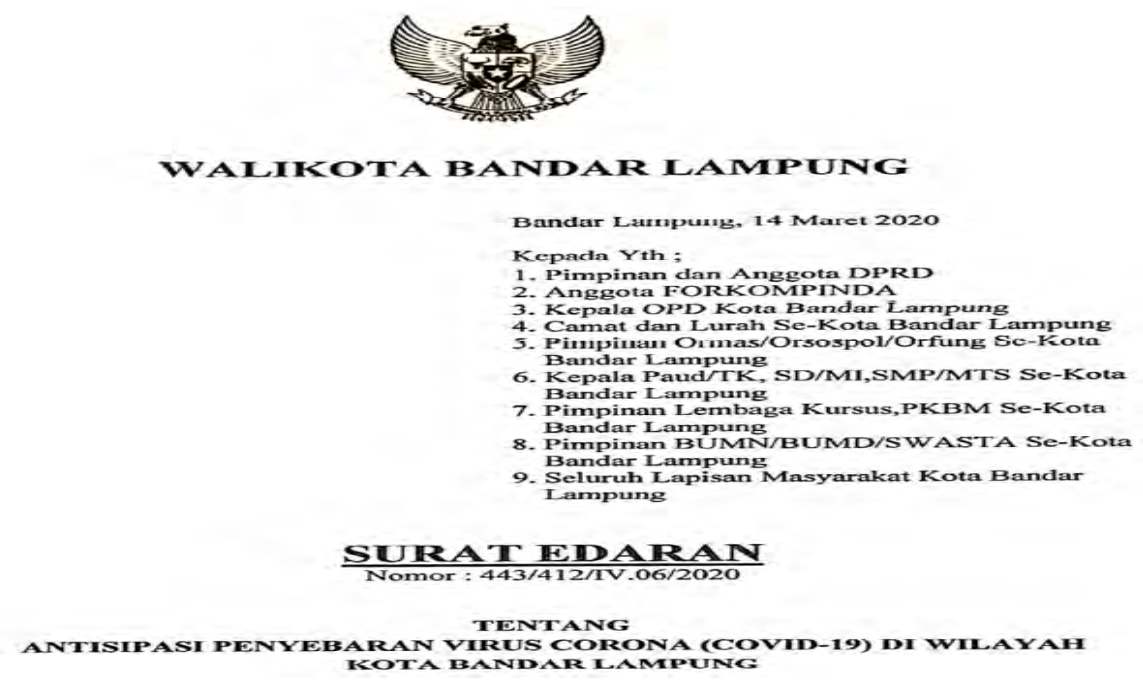

Figure 4. Anticipating the Spread of Corona Virus in the City of Bandar Lampung

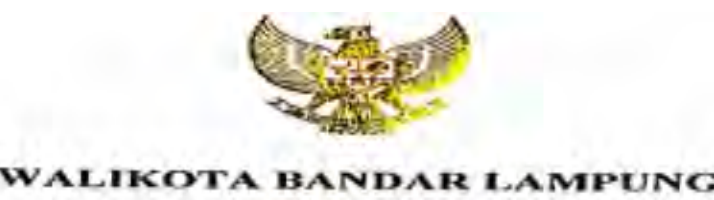

WALIKOTA BANDAR LAMPUNG

Bandar Lampunis. 21 Jamaari 2021

Kegada rill:

Para Fimpinan I Manager Itotel, Pemilik Ciedumg Portermuan, Manajemen Pusas. Manakter Karanke. Pernilik Tempat liburan Tainoya dan Seluruh

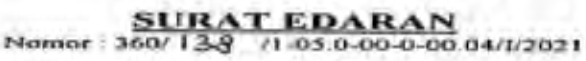

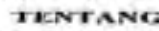

Menindaklanjuti hasil rapat pannmeanai COYiD-10 oleh Stotuan Tugas COVID 19 Provinsi Lampung yang dipimpin oleh Gubernur Lampung dan dihadiri Ketwi DPRD Provinsi Lampung bersame selunsh Forkopimda trovinsi Lampune secan lentekap sera setsuruh

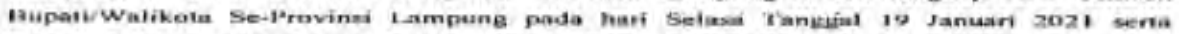
memperhatikan periyebaran Corons Virus Disease (COVID-10) yang eenderung tenus meningkat dan wakiv ke wakn menimbulkan korban jiwo das kerustian makeriat yang besar dan telah betimplikasi pada keludursin masyarakat baik aspeli sosial, ekenomi, ksoejahtersan masyarakat dan dampai saat ini Pasien COVID-19 Kota tsandar Lampung burjumlah 3,460

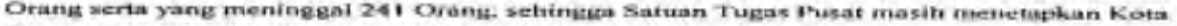
Bandar 1-ampung sebacai ZONA MEteAM.

Untuk itu diberiahukan kepade seluruh unasyrakas Kona Bandar Lampumg

1. Tidak menuadakan acara resepsi (Pesta Pernikuhan, Khitunan, Utang Tahun dan lain.tain).

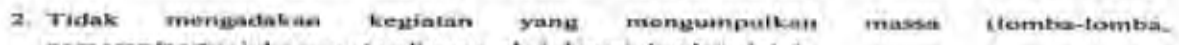
pameran/periunjukan, pertandingan, aksi damai din (min-iaim).

3. Acara akad nikah dapet ditaksanakan derngan ketentuan :

- Dihadiri maksimal so Orang:

b. Waktu pelakaanaan maksteral 2 jam

C. Melaksanakan penerapan protokof kesehation secara ketais.

d. Tidak mentisunakin hibarantive mustc.

- Mendapat rekomendasi dari Satian Tugas Covir-19 Kota t3andar tampung-

Figure 5. Restrictions on Activities in the City of Bandar Lampung 
Various policies regarding the implementation of education at home are a form of large-scale social restrictions. Restrictions on activities that move many people, and as a form of anticipation for the development of larger virus transmission, so that pandemic management can be implemented effectively and efficiently.

However, the implementation of distance learning policies has challenges in its implementation. This challenge is in the form of human resources such as teachers who have not compiled learning programs with various conditions. Learning facilities have not fully supported the implementation of distance learning; so far, distance learning uses electronic devices, but not all have them and can use them. Besides that, the cost of buying pulses with smooth signal support is not evenly distributed. Implementation arrangements are still varied, the understanding of leaders and implementers is not comprehensive (Arifa, 2020). Teachers are still carrying out the learning process to achieve curriculum targets ("Commissioner of KPAI Unloading Distance Learning Problems," 2020). This is quite contrary to a circular regarding schools that are not obliged to achieve complete learning, so that it becomes a burden for teachers and students during a pandemic. Various policies of the ministry of education and local government related to the implementation of education refer to the regulation of the minister of health as a ministry that is directly related to the management of disease outbreaks (Kemenkes RI, 2020). The Ministry of Health's regulations states that disease outbreaks can be controlled through limiting interactions between humans; the less interaction, the less potential for transmission. In the scope of schools, organizational culture is a factor covering the implementation of learning during this pandemic. The development of a school organizational culture in schools is based on the school's context and the higher school organizational culture. School organizational culture describes the rules of behavior, norms, dominant values, philosophy, rules and organizational climate. Rules of behavior in the form of a religious system that surrounds them, such as not plunging themselves into damage, cleanliness is part of faith, with healthy conditions can carry out divine and social worship. Leadership is a factor that can affect teacher performance (Yuneti et al., 2019). Based on this research, it can be seen that leadership can change the behavior of school residents to face the pandemic with a comprehensive understanding. Leaders with their knowledge, attitudes, and behavior can influence school residents to form attitudes and behaviors that can prevent a pandemic so that they can be healthy. In addition to the leadership of the principal, teachers are also agents of behavior change communication, because teachers are the ones who carry out their duties professionally (Aliyyah et al., 2019), the teacher's job is as a source of knowledge with social, professional, and spiritual competencies. The application of management information systems as an organizational aspect can be an appropriate learning tool to achieve organizational goals (Adisel, 2019). The application of information system management as a means of providing access to information and 
communication about pandemics must be done both in schools, residences, and the wider community. The application of well-planned and well-managed management of information systems as a means of social mobilization, from those who do not understand to those that do not. The application of human resource management in the school environment is also a means of social mobility. The implementation of human resource management starts from planning to carrying out professional evaluations (Sakban et al., 2019). With human resource management, social mobility is implemented by increasing the motivation of school members to understand and behave in a clean and healthy life. Here, the principal who can direct and coordinate (Hamidi et al., 2019) with human resources is important in social mobility to understand healthy behavior.

Schools are part of society's social capital, providing a safe, supportive learning environment to the students, providing jobs to teachers and supporting staff, and allowing parents and guardians to carry out their professions. Communities should make every effort to support the reopening of schools safely for in-person learning in the next few weeks and months. From other countries, we know that schools can reopen safely for in-person learning in communities with low rates of Covid-19 spread if appropriate precautions are taken. In such groups, representation of the professional body could be useful for highlighting the scientific evidence of certain preventive strategies. Schools can implement strategies across 4 key areas to reduce the spread of Covid-19: 1. Promoting healthy behaviors that reduce spread (e.g., social distancing, washing hands, and wearing cloth face coverings), 2. Maintaining healthy environments (e.g., ensuring proper ventilation, cleaning, and disinfecting frequently touched surfaces), 3. Maintaining healthy operations (e.g., staggering schedules, keeping students in small groups, Cohorting, Alternative schedule, Hybrid model, blended learning), and 4. Preparedness for any eventuality or development of signs and symptoms. Besides that, School administration can take everyday preventive actions to protect themselves and others from getting infected. Washing hands often with soap and water for at least 20 seconds is the easiest practice that all can adopt. If soap and water are not readily available, a hand sanitizer containing more than $60 \%$ alcohol is a good alternative. Cover all surfaces of hands and rub them together until they feel dry. Covering coughs and sneezes with a tissue or inside the elbow, throwing the tissue away, and washing hands. Avoid touching one's eyes, nose, mouth, and face cover or mask. Maintaining a distance of at least 6 feet from other adults and from students when feasible. Wearing a face mask covering nose and mouth, especially when other social distancing measures are difficult to maintain. Cleaning and disinfecting frequently touched surfaces, including tables, doorknobs, light switches, countertops, handles, desks, phones, keyboards, toilet sheet or tap, faucets, and sinks. Staying home when sick or after being in close contact with a person with COVID-19. Initially, such places and objects can be avoided where transmission through fomites is higher such as gyms, physical education equipment, 
games equipment, etc. School buses and other transport mediums of students are a common source of virus transmission. Therefore, drivers and carers should practice all safety measures and adhere to all protocols (e.g., hand hygiene, face mask, keeping the cleanliness of buses, seats, etc.). Similar to frequently touched surfaces, buses should be cleaned and disinfected at least daily using disinfectants. Students should be seated within distance in buses and always use face masks to avoid overcrowding in the bus. However, students who live in the same household may sit together if needed. If students wear face masks, then sitting two in a row may not be a transmission problem (Kishore J, 2020).

\section{Discussion}

In principle, in the organization, there are two fundamental elements. First, the organization comes as an idealistic element in which it has a belief in the form of a basic assumption and values that every organizational player can use as a guideline in behaving. Second, the organization can be an element of a behavioral nature; it is intended that the organization is able to show itself as a visible activity and easy to observe.

The organization of its presence can make itself implement a strategy to have a comprehensive planning formulation of how the organization can achieve its mission and objectives. The strategy contained in the organization will be able to maximize the advantages of a competitive nature and minimize the limitations of the organization in the competition with other organizations.

As Schein classifies the cultural aspects of the organization into 3 parts, the organizational culture includes; first, culture comes as an artifact that is an organization containing various things that can be seen, heard, and felt by every member of the organization when encountered. So, when this aspect comes with a new habit era new normal, then each member of the organization feels there is an ease to run because new habits can be seen and felt. Second, there is a belief and value embraced by each member of the organization. This eventually gave rise to ideals, goals, values, aspirations, ideology, and rationalization. So that when the activities or activities of the organization switch to new habits era new normal, making each organization lose a social value order that the organization has run. Third, there is a basic assumption that ultimately implies and guides every direction of the organization both in acting and sharing with its members. This aspect makes the organization have the smallest aspect in creating organizational culture. So that this new normal era makes members of the organization become more understanding and feel what to do in the middle of this new habit.

The conditions that occurred above have created a new habit for the organization. This is because all organizations were hit by the Covid-19 pandemic, which eventually made the organization not run as usual, and there were delays to the planned programs. 
Strategy in an organization comes as a generalship or an activity carried out by the armed forces' leadership while determining the plan of conquest and winning a war. Strategy comes as a way to achieve what is the goal. Therefore, art that has become part of the strategy has important activities needed by the organization to achieve its goals. Organizations that apply a strategy take some skills to support their sustainability. So, the organization's ability takes the name of creative thinking \& problem-solving ability, the ability to communicate \& collaborate, as well as the ability to create and innovate. Organizations that successfully grow well will develop competitive strategies by looking at existing opportunities and conducting continuous development. Organizational competition should be seen by the organization as a motivation in developing quality organizational sustainability so that innovation can run well as the foundation. The organization in this new normal era must be able to pass the biggest challenges for the sustainability of its organization. Organizations are required to run their organizations with this new change, namely by making a positive response and developing to create a culture without changing the noble traditions that already exist (Syadzili, 2021).

Schools in organizational sociology studies have 3 (three) major powers in implementing their duty and reaching the goal, power, an institution, social network, and cognitive frame (Ricardi S. Adnan, 2019). Institutions are the norms and rules that become the reference; the school organization refers to the law, especially the law basic 1945, Constitution system national education, various ministerial regulations that regulate in detail about school management, joint regulations governing the coordination and interaction of sector lines, local regulations that govern the implementation of schools with all their uniqueness. The existence of sanctions shows strong aspect institutions if they fail to meet norms, both administrative sanctions, and criminal sanctions. A thinking framework is a mindset or attitude towards human actors as implementers of norms, perceptions of what and how these norms affect the functioning of social organizations, and how norms are enforced.

Social networking is a culture in school organizations' operations and social relations, such as the kinship aspect that gives rise to nepotic practices that place poor-quality human resources. Institutional studies show the relationship between actors and their frame of mind owned (Beckert, 2018).

In studying complex adaptive systems, complex organism-like structures as described could develop regularity and achieve goals over time. The organization is described by the semi-autonomous organizational members interacting on various levels of knowledge and action that can be described in context and the driving mechanisms of a complex adaptive systems theory. A complex adaptive system is a framework for studying, explaining an agency/actor/implementer system that collectively shapes the overall behavior. With this approach, it can describe how the agent/actor/individual 
behaves produces patterns that emerge through interrelated feedback throughout an organization's systems, feedback that creates and reinforces attractiveness, patterns of behavior that are continually out of balance, or regularity expected (Carmichael \& Hadzikadic, 2019).

In Beckert's study of institutional sociology, there is a capitalist environment, where agents have calculations in the future. With this consideration, the agent will choose what action to take. However, agents also have experience, so that apart from future considerations, past experiences also influence the agent's actions. Agents have within the framework of complex adaptive systems, agent/actor networks are interdependent and interact in dynamics by goals, point of view, and their respective needs. They are a mutable structure with many continuous hierarchies. The complex adaptive system is connected in interactive network dynamics. Various members of the skills and resources in an organization require a leadership role. Dynamic organizations in an environment where each works freely and is tied to their respective duties to contribute to achieving the main goals (Turner et al., 2018).

Adaptive complex systems depart from organizational complexity theory. Organizations as complex adaptive systems focus on generating innovations. Complex adaptive systems have a common feature, namely non-linear self-organization, which is important to consider in management. It is not linear, meaning that what is input is not proportional to the output. Small changes in a unit can take a big effect on the whole system. The existence of new relationship patterns is a result of connection patterns between various agents. Agent interactions also give rise to new structures, patterns, and behaviors in the system. The Organization continues to make adjustments through various feedback appearances. Organizations exist in various conditions, both linear and non-linear. A complex adaptive system that exists in an environment but becomes part of the environment itself. Nested systems, systems within systems. The adaptive system cannot be returned to its original form or state (Mubarok, 2017).

Model relationship in the development of human security systems in life or group of organizations. The socio-ecological analysis is an inclusive, interdisciplinary approach. Socio-ecological is a system related to and influenced by various social systems. The existence of interdependence of organisms, in this case, there is a tendency to interdependence. The unity of the organism indicates the existence of units that each other depends on. Awareness of individuals as a basis in investing time and effort to develop institutional. The network of various components, big-small, affects how a system works continuously to face internal and external challenges (Hafsaridewi et al., 2018). 
The socio-ecological model is the frame of mind that different levels of and layers of society, such as families, groups, work, living environments, and local and national policies, affect individuals and families' behavior. The three principles of socioeconomic shortlist are environmental and human interact dynamically, not only the physical environment but also the social environments at various levels, resulting in individual changes in and context are simultaneously more effective and larger, than the behavior of Individual. The socio-ecological model is the interaction between sources of resources, users, public service providers, and others. Therefore, socio-ecological analysis has two stages: identifying key components and analyzing the interactions between components of socioecological-forming units. Component identification sub-stages the main are: analyzing the characteristics of resources, resource users, providers of public infrastructure, and frogs of public infrastructure. Sub stages interaction analysis activities between forming components is to analyze the resource relationship with resource user, data source user with infrastructure providers, infrastructure providers with infrastructure, infrastructure with resources, public infrastructure with resources with resource users, resource users with infrastructure, resources with infrastructure, resources with infrastructure providers.

\section{Conclusion}

The time of the pandemic has various implications sector, including sector education. As a complex system, the organization is expected to become an organization that can promote healthy behavior physically and mentally during a pandemic. The school organization is covered by an individual with knowledge, attitudes, and behavior. Therefore, behavior change communication is very important to be strategically arranged based on data for monitoring and evaluation and capacity building of school residents in pandemic conditions. The school organization is surrounded by individuals and social groups; therefore, social groups could take that effect to organize schools facing a pandemic. The public covers the school organization with relationships between organizations or communities to adapt communication and social needs to pandemic conditions. Social institutions and institutions also surround school organizations; therefore, social mobility is the main action in promoting health programs during a pandemic. School organization refers to policy advocated. (Future study) 


\section{References}

Adisel. (2019). Manajemen Sistem Informasi Pembelajaran. Alignment: Journal of Administration and Educational Management, 2(2), 105-112. Https://Doi.Org/10.1016/J.Surfcoat.2019.125084

Aliyyah, R. R., Widyasari, Mulyadi, D., Ulfah, S. W., \& Rahmah, S. (2019). Guru Berprestasi Sumber Daya Manusia Pengembang Mutu Pendidikan Indonesia.

Arifa, F. N. (2020). Tantangan Pelaksanaan Kebijakan Belajar Dari Rumah Dalam Masa Darurat Covid-19. Info Singkat;Kajian Singkat Terhadap Isu Aktual Dan Strategis, XII(7/I), 6. Retrieved From Http://Berkas.Dpr.Go.Id/Puslit/Files/Info_Singkat/InfoSingkat-XII-7-I-P3diapril-2020-1953.Pdf

Beckert, J. (2018). The Future In Economic Action: A Reply To The Reviewers. Distinction: Journal of Social Theory, 19 (3), 344-352.

Hamidi, Nuzuwar, \& Nurmal, I. (2019). Peran Kepala Sekolah Sebagai Administrator Dan Supervisor. Alignment: Journal of Administration and Educational Management, 2(1), 39-47. Https://Doi.Org/10.4324/9781315853178.

Jamaluddin, D., Ratnasih, T., Gunawan, H., \& Paujiah, E. (2020). Pembelajaran Daring Masa Pandemik Covid19 Pada Calon Guru : Hambatan, Solusi Dan Proyeksi. Karya Tulis Ilmiah UIN Sunan Gunung Djjati Bandung, 1(1), 1-10. Retrieved From Http://Digilib.Uinsgd.Ac.Id/30518/

Carmichael, T., \& Hadzikadic, M. (2019). The Fundamentals of Complex Adaptive Systems. In Princeton University Press (Pp. 431-436). Https://Doi.Org/10.1007/978-3-030-20309-2

Wang, G., Zhang, Y., Zhao, J., Zhang, J., \& Jiang, F. (2020). Mitigate The Effects Of Home Confinement On Children During The Covid-19 Outbreak. The Lancet, 395(10228), 945-947.

Hafsaridewi, R., Khairuddin, B., Ninef, J., Rahadiati, A., \& Adimu, H. E. (2018). Pendekatan Sistem SosialEkologi Dalam Pengelolaan Wilayah Pesisir Secara Terpadu Sosial- Ecological System ( SES ) Approach In Integrated Coastal Management. Buletin Ilmiah “MARINA” Sosial Ekonomi Kelautan Dan Perikanan, 4(2), $61-74$.

Kemenkes RI. (2020). Peraturan Menteri Kesehatan Republik Indonesia Nomor 9 Tahun 2020 Tentang Pedoman Pembatasan Sosial Berskala Besar Dalam Rangka Percepatan Penanganan Corona Virus Disease 2019 (Covid-19). Kementerian Kesehatan RI, 28. Retrieved From :

Http://Hukor.Kemkes.Go.Id/Uploads/Produk_Hukum/PMK_No_9_Th_2020_Ttg_Pedoman_Pembatasan_So sial_Berskala_Besar_Dalam_Penanganan_COV ID-19.Pdf

Kementerian Pendidikan Dan Kebudayaan, R. I. Surat Edaran Nomor 4 Tahun 2020 Tentang Pelaksanaan Kebijakan Pendidikan Dalam Masa Darurat Penyebaran Coronavirus Disease (COVID-19). , (2020).

Kementerian Pendidikan Dan Kebudayaan Republik Indonesia. Surat Edaran Nomor 15 Tahun 2020 Tentang Pedoman Penyelenggaraan Belajar Dari Rumah Dalam Masa Darurat Penyebaran Covid-19. , (2020).

Kishore, J. (2020). Reopening of School in COVID 19 Pandemic. Indian Journal of Youth and Adolescent Health (E-ISSN: 2349-2880), 7(1), 23-26.

Komisioner KPAI Bongkar Permasalahan Pembelajaran Jarak Jauh. (2020). Retrieved June 14, 2020, From Https://Mediaindonesia.Com/Read/Detail/309647-Komisioner-Kpai-Bongkarpermasalahan-Pembelajaran-JarakJauh.

Mubarok, M. H. (2017). Kompleksitas Model Bisnis Adaptif Berbasis Teknologi Digital Dan Jaringan Bisnis. MALIA, 1, 57-70. 
Nurochim, N., \& Ngaisah, S. (2020). Organisasi Sekolah Di Masa Pandemi. Alignment: Journal of Administration and Educational Management, 3(2), 154-167.

Pujilestari, Y. (2020). Dampak Positif Pembelajaran Online Dalam Sistem Pendidikan Indonesia Pasca Pandemi Covid-19 Adalah, 4(1), 49-56. $\quad$ Retrieved :Http://Journal.Uinjkt.Ac.Id/Index.Php/Adalah/Article/View/15394/7199

Purwanto, A., Pramono, R., Asbari, M., Santoso, P. B., Wijayanti, L. M., Choi, C. H., \& Putri, R. S. (2020).Studi Eksploratif Dampak Pandemi Covid-19 Terhadap Proses Pembelajaran Online Di Sekolah Dasar. Edupsycouns: Journal of Education, Psychology and Counseling, 2(1), 1-12.

Ricardi S. Adnan. (2019). Bencana, Kelembagaan, Dan Masyarakat. Talenta Conference Series: Local Wisdom, Social, And Arts (LWSA), 2(1), 1-11.

Sakban, Nurmal, I., \& Ridwan, R. Bin. (2019). Manajemen Sumber Daya Manusia. Alignment: Journal of Administration and Educational Management, 2(1), 93-104. Https://Doi.Org/10.4324/9781315853178

Suryahadi, A., Al Izzati, R., \& Suryadarma, D. (2020). The Impact Of COVID-19 Outbreak on Poverty: An Estimation For Indonesia.

Syadzili, M. F. R. (2021). Pengembangan Budaya Organisasi Di Era New Normal.

Turner, J. R., Baker, R., \& Morris, M. (2018). Complex Adaptive Systems: Adapting and Managing Teams and Team Conflict. In Organizational Conflict: Vol. I $($ Pp. $65-93$ ). Https://Doi.Org/Http://Dx.Doi.Org/10.5772/57353.

Viner, R. M., Russell, S. J., Croker, H., Packer, J., Ward, J., Stansfield, C., Booy, R. (2020). School Closure And Management Practices During Coronavirus Outbreaks Including Covid-19: A Rapid Systematic Review. The Lancet Child And Adolescent Health,4(5),397-404.

World Bank Group Education. (2020). What Can Brazil Learn From The Rest Of The (Vol. 131, Pp. 2-5). Vol. 131, Pp. 2-5.

Yuneti, A., Hamdan, \& Prananosa, A. G. (2019). Kepemimpinan Partisipatif Dan Komunikasi Kepala Sekolah Terhadap Kinerja Guru. Alignment: Journal of Administration and Educational Management, 2(2), 113-125. Https://Doi.Org/10.1017/CBO9781107415324.0 